University of Nebraska - Lincoln

DigitalCommons@University of Nebraska - Lincoln

Nile Tilapia and Blue Tilapia Fry Production in a Subtropical Climate Based on Degree Days

\author{
Bartholomew W. Green \\ USDA, Agricultural Research Service, bart.green@usda.gov \\ Esam H. Rizkalla \\ Ministry of Agriculture and Land Reclamation, Egypt
}

Follow this and additional works at: https://digitalcommons.unl.edu/usdaarsfacpub

Part of the Agriculture Commons, and the Aquaculture and Fisheries Commons

Green, Bartholomew W. and Rizkalla, Esam H., "Nile Tilapia and Blue Tilapia Fry Production in a Subtropical Climate Based on Degree Days" (2015). Publications from USDA-ARS / UNL Faculty. 2477. https://digitalcommons.unl.edu/usdaarsfacpub/2477

This Article is brought to you for free and open access by the U.S. Department of Agriculture: Agricultural Research Service, Lincoln, Nebraska at DigitalCommons@University of Nebraska - Lincoln. It has been accepted for inclusion in Publications from USDA-ARS / UNL Faculty by an authorized administrator of DigitalCommons@University of Nebraska - Lincoln. 


\section{Nile Tilapia and Blue Tilapia Fry Production in a Subtropical Climate Based on Degree Days}

\section{Bartholomew W. Green \& Esam H. Rizkalla}

To cite this article: Bartholomew W. Green \& Esam H. Rizkalla (2015) Nile Tilapia and Blue Tilapia Fry Production in a Subtropical Climate Based on Degree Days, Journal of Applied Aquaculture, 27:2, 132-143, DOI: 10.1080/10454438.2015.1045767

To link to this article: https://doi.org/10.1080/10454438.2015.1045767

曲 Published online: 09 Jun 2015.

Submit your article to this journal $₫$

山 Article views: 83

Q View related articles $\longleftarrow$

View Crossmark data $\nearrow$ 


\title{
Nile Tilapia and Blue Tilapia Fry Production in a Subtropical Climate Based on Degree Days
}

\author{
BARTHOLOMEW W. GREEN ${ }^{1}$ and ESAM H. RIZKALLA ${ }^{2}$ \\ ${ }^{1}$ Department of Fisheries and Allied Aquacultures, Auburn University, \\ Auburn, Alabama, USA \\ ${ }^{2}$ Central Laboratory for Aquaculture Research, Agricultural Research Center, \\ Ministry of Agriculture and Land Reclamation, Abbassa, Sharkia, Egypt
}

\begin{abstract}
The relationship between production in subtropical earthen ponds of fry suitable for hormonal sex inversion and degree days was quantified for Nile tilapia (Oreochromis niloticus; Egypt strain) and blue tilapia (O. aureus). Degree days were calculated for each trial as the sum of mean daily water column temperature minus the reference temperature, $15^{\circ} \mathrm{C}$. No fry from either species were harvested at fewer than 124-126 degree days. Total fry production for each increased linearly as cumulative degree days increased from 129 to 281 degree days. Production of fry suitable for hormonal sex inversion was positively related to cumulative degree days only from 115 to 215 degree days. Tilapia fry too large for hormonal sex inversion were not observed until greater than 200 cumulative degree days and increased with increasing degree days thereafter. Optimal production in earthen ponds in a subtropical climate of Nile tilapia and blue tilapia fry suitable for hormonal sex inversion was obtained at 190-215 degree days.
\end{abstract}

KEYWORDS Earthen ponds, fry size distribution, hormonal sex inversion, Oreochromis aureus, Oreochromis niloticus

\section{INTRODUCTION}

A consistent, reliable supply of fingerlings of the desired species, sex, and size is critical to the success of any aquacultural enterprise. Tilapia

Address correspondence to Bartholomew W. Green, USDA-ARS Harry K. Dupree Stuttgart National Aquaculture Research Center, P.O. Box 1050, 2955 Highway 130 East, Stuttgart, AR 72160, USA. E-mail: bart.green@ars.usda.gov 
production ponds typically are stocked with monosex male Nile tilapia (Oreochromis niloticus); often, these monosex fingerlings are produced by hormonal sex inversion using $17 \alpha$-methyltestosterone, although populations of male tilapia also are obtained increasingly by crossing genetically male tilapia (YY genotype) with normal females and less commonly by interspecific hybridization, e.g., Nile (O. niloticus) $\times$ blue (O. aureus) tilapia or by manual separation of sexes based on visual examination of the genital papilla (Beardmore et al. 2001). Blue tilapia are grown less commonly than Nile tilapia but may be more appropriate for subtropical regions because of greater tolerance to lower water temperatures (Starling et al. 1995; Rezk et al. 2002).

Harvest of tilapia fry from earthen reproduction ponds is a common method for producing fry suitable for sex inversion. One harvest strategy involves frequent partial harvests whereby schools of swim-up fry are harvested once to six times daily using hand nets or small seines (Guerrero 1986; Verdegem and McGinty 1989). Harvested fry that pass through a $3-\mathrm{mm}^{2}$ mesh grader are suitable for sex inversion. Although daily fry production is a positive attribute of this strategy, obtaining large numbers of same-age fry can be difficult, and fry from early spawns that escape capture will cannibalize newly hatched fry from later spawns, which can result in a marked reduction in numbers of target fry captured. Thus, reproduction ponds must be drained periodically to eliminate larger fingerlings.

Another strategy in which large numbers of fry suitable for sex inversion are produced involves complete harvest of the earthen reproduction pond every 17-19 d after stocking with broodfish (Rothbard et al. 1983; Hulata 1997). Harvest time is based on the assumed reproductive cycle of tilapia (Rothbard et al. 1983). Water temperature varies seasonally and is known to affect fish reproduction and growth. In a study on the production in earthen ponds in the tropics of Nile tilapia fry for sex inversion, Green and Teichert-Coddington (1993) related fry production to cumulative degree days since broodfish stocking and showed optimal production occurred after 195-220 degree days. Degree days are calculated by subtracting a threshold temperature ("biological zero") from the mean daily temperature; the threshold temperature is the temperature below which development is halted by cold and is not necessarily $0^{\circ} \mathrm{C}$ (Pruess 1983; Regier et al. 1990). Green and Teichert-Coddington (1993) used $15^{\circ} \mathrm{C}$ as the threshold temperature for their degree-day calculations for Nile tilapia reproduction. Mean lower lethal temperature for the Nile tilapia Egypt strain is reported to be $10.0^{\circ} \mathrm{C}$ compared to $14.1^{\circ} \mathrm{C}$ and $12.2^{\circ} \mathrm{C}$ for the Ghana and Ivory Coast strains respectively (Khater and Smitherman 1988). Blue tilapia cease spawning when average weekly water temperature is $19.4^{\circ} \mathrm{C}$ (Aureli and Torrans 1988). Lower lethal temperature for blue tilapia is reported to range from 5 to $13^{\circ} \mathrm{C}$ (Starling et al. 1995).

Most research on tilapia fry production in earthen ponds is conducted in the tropics, and only one study addressed pond production in the subtropics 
of tilapia fry for hormonal sex inversion. The objectives of this study were to quantify the relationship between cumulative degree days and the production in earthen ponds in a subtropical climate of Nile tilapia (Egypt strain) fry of a size suitable for hormonal sex inversion and to determine if a similar relationship exists for blue tilapia. To be consistent with Green and Teichert-Coddington (1993), we used $15^{\circ} \mathrm{C}$ as the threshold temperature for degree-day calculations for Nile and blue tilapia fry production.

\section{MATERIALS AND METHODS}

This research was carried out in ten 0.01-ha earthen ponds at the Central Laboratory for Aquaculture Research, Abbassa, Egypt, which is located about $60 \mathrm{~km} \mathrm{NE}$ of Cairo at $30^{\circ} 32^{\prime} \mathrm{N}$ latitude and has an arid, subtropical climate. Ponds each were equipped with a $6-\mathrm{m}^{2}$ concrete harvest basin located in the vicinity of the drain pipe. Average pond water depth was $50 \mathrm{~cm}$; water was added periodically to replace losses to evaporation and seepage. Prior to pond inundation a piece of $1.28-\mathrm{cm}$ square mesh netting was draped over the harvest basin and held in place with rocks. Ponds were filled by gravity using water from a small irrigation canal that originated at the Ismalia canal; each pond inlet was fitted with a saran screen filter to exclude introduction of feral fish. The pond drain pipe was fitted with a $1-\mathrm{mm}^{2}$ mesh screen. Ponds were left empty between cycles, and any puddles remaining on the pond bottom were treated with granular calcium hypochlorite prior to reflooding.

This research was replicated through time in 26 independent trials (replicates) for each species conducted between April and November. Broodfish for each trial were stocked randomly into one to two ponds, depending upon pond availability. Ponds were harvested 13-20 d after stocking. Female buccal cavities were inspected prior to stocking to ensure none was incubating eggs/sac fry. Broodfish sex ratio was 1.5 female: 1 male. Nile tilapia broodfish were stocked at 0.9 fish $/ \mathrm{m}^{2}$; females averaged (mean $\pm S D$ ) $147 \pm 35 \mathrm{~g}$, and males averaged $219 \pm 69 \mathrm{~g}$. Blue tilapia broodfish were stocked at $1.0 \mathrm{fish} / \mathrm{m}^{2}$; females averaged $92 \pm 28 \mathrm{~g}$, and males averaged $170 \pm 48 \mathrm{~g}$. Broodfish were fed a $25 \%$-protein pelleted commercial ration at $2 \%$ of fish biomass daily.

At harvest, the pond water level was lowered until only the sump had water. The netting in the sump was lifted to remove the broodfish en masse; broodfish were transferred to a hauling tank for transport to concrete holding tanks where fish were segregated by sex and held for about 5-7 d until restocking in reproduction ponds. Fry were harvested with dip nets (1.6-mm ace nylon mesh) and graded through 3.2-mm square mesh plastic netting. The number of fry trapped in puddles on the pond bottom or impaled on the drain screen was not estimated. Fry that passed through the grader (target 
fry) were collected in a $2-\mathrm{m}^{2}$ hapa (1.6- $\mathrm{mm}$ ace nylon mesh) suspended in $28-\mathrm{m}^{2}$ concrete tanks, and fry number was estimated by visual comparison to a counted standard after manually removing any aquatic insects that were present. A sample of 100 target fry was measured individually for total length (TL) and was weighed en masse to determine average weight. Total weight of fry retained by the grader also was determined, and a sample of 100 retained fry was weighed en masse to determine average individual weight and was measured individually for TL. Total number of fry retained by the grader was estimated by dividing total weight by average individual weight. The numbers of target fry and retained fry were summed to obtain the total number of fry harvested per pond.

Water temperatures in three ponds were monitored continuously by a computerized data logger (CR10X, Campbell Scientific, Inc., Logan, UT, USA); temperature sensors in each pond were mounted at depths of $5 \mathrm{~cm}$ and $35 \mathrm{~cm}$. Mean hourly water column temperature was calculated. Degree day was calculated by subtracting the base temperature $\left(15^{\circ} \mathrm{C}\right)$ from the mean hourly water column temperature (Green and Teichert-Coddington 1993). Accumulated degree days for each trial were obtained by summation.

Data were analyzed by mixed models analysis of variance and covariance (PROC MIXED), and regression analysis (PROC REG) procedures of SAS version 9.4 (SAS Institute, Cary, NC, USA). Species was the fixed effect and stocking date was the random effect (block) in the MIXED analysis. Retained fry data were log transformed prior to regression analysis to stabilize the variance. Differences were considered to be significant at $\alpha=0.05$.

\section{RESULTS}

Cumulative degree days for the 13-20-d trials followed the seasonal trends in mean water column temperature (Figure 1). Mean daily pond water temperature ranged from 17.7 to $30.2^{\circ} \mathrm{C}$ and averaged $27.0 \pm 0.9^{\circ} \mathrm{C}$ during these trials. Across all trials there was an average of 211 cumulative degree days (range: 86-281).

Fry were harvested in all but three trials for each species. The estimated total number of fry harvested from the 26 trials/species was 443,521 and 436,999 for Nile and blue tilapia respectively, of which $79 \%$ and $74 \%$, respectively, were target fry. Coefficients of variation for total fry production (fry/g female) across all trials were $59.1 \%$ for Nile tilapia and $70.3 \%$ for blue tilapia. Total fry production per harvest averaged $( \pm$ SE) $115.5 \pm 11.7$ and $112.5 \pm 11.8 \mathrm{fry} / \mathrm{m}^{2}(P=0.788)$, and target fry production per harvest averaged $91.5 \pm 9.4$ and $83.3 \pm 9.6$ fry $/ \mathrm{m}^{2}(P=0.336)$ for Nile and blue tilapia respectively. Nile tilapia target fry averaged $9.2 \pm 0.1 \mathrm{~mm}$ TL, and blue tilapia target fry averaged $8.9 \pm 0.1 \mathrm{~mm} \mathrm{TL}(P=0.108)$, whereas retained fry 


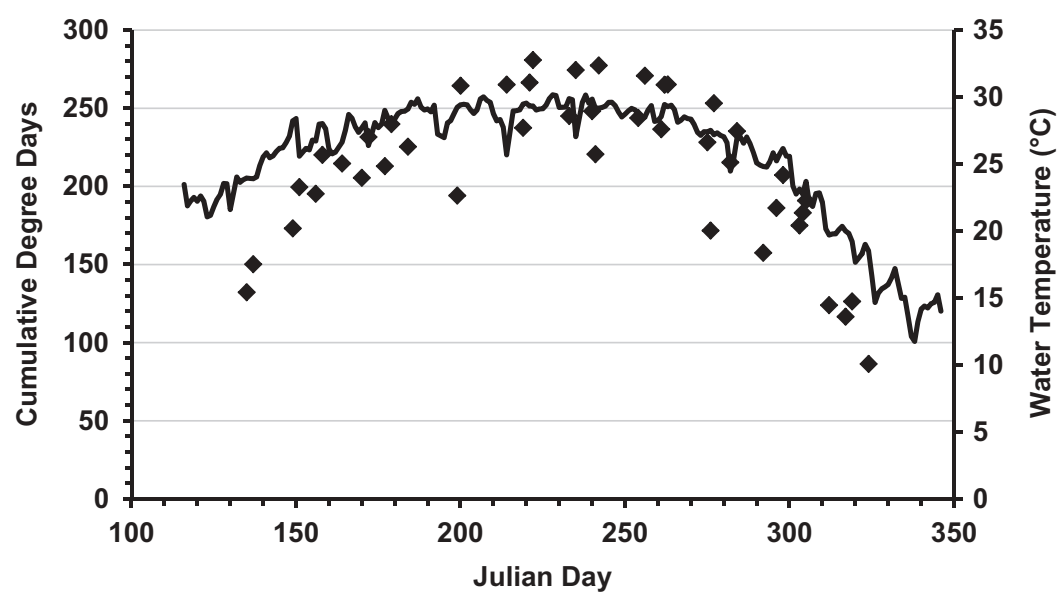

FIGURE 1 Mean water temperature ( $(-)$ and cumulative degree days ( $)$ for tilapia fry production trials ending on the indicated Julian day. In each of 26 trials/species, Nile tilapia (Oreochromis niloticus) or blue tilapia (O. aureus) broodfish were stocked into 0.01-ha earthen ponds and all broodfish and fry were harvested by draining the pond after 13-20 days.

averaged $14.6 \pm 0.3 \mathrm{~mm}$ TL and $14.6 \pm 0.3 \mathrm{~mm} \mathrm{TL}(P=0.981)$, respectively (Figure 2). Retained fry for both species ranged from 11 to $20 \mathrm{~mm}$ TL.

Nile tilapia fry were not observed at fewer than 124 degree days and blue tilapia fry were not observed at fewer than 126 degree days. Females incubating eggs and/or sac fry were observed at harvest, but egg and sac fry numbers were not quantified. Total fry production (fry/g female, $y$ ) increased linearly as cumulative degree days $(x)$ increased and was described by the equation $y=0.012 x-1.019\left(P<0.001, R^{2}=0.461\right)$ for Nile tilapia and $y=0.018 x-2.016\left(P<0.001, R^{2}=0.489\right)$ for blue tilapia; covariance analysis indicated that regression line slope did not differ significantly between species. Production of target fry over the entire range of cumulative degree days (approximately 125-281 degree days) was independent of cumulative degree days for Nile tilapia $\left(P=0.191, R^{2}=0.048\right)$ and blue tilapia $\left(P=0.314, R^{2}=0.029\right)$. However, target fry production was positively related to increased cumulative degree days over the range 115-215 degree days and was described by the equation $y=0.015 x-1.567(P<0.001$, $\left.R^{2}=0.540\right)$ for Nile tilapia and $y=0.018 \mathrm{x}-2.00818411(P=0.002$, $\left.R^{2}=0.456\right)$ for blue tilapia; covariance analysis indicated that regression line slope did not differ significantly between species. Retained fry were not observed until greater than 200 cumulative degree days. Production of logtransformed retained fry increased linearly with increasing cumulative degree days for Nile $\left(P<0.001, R^{2}=0.428\right)$ and blue $\left(P<0.001, R^{2}=0.437\right)$ tilapia; covariance analysis indicated regression line slope did not differ significantly between species. 

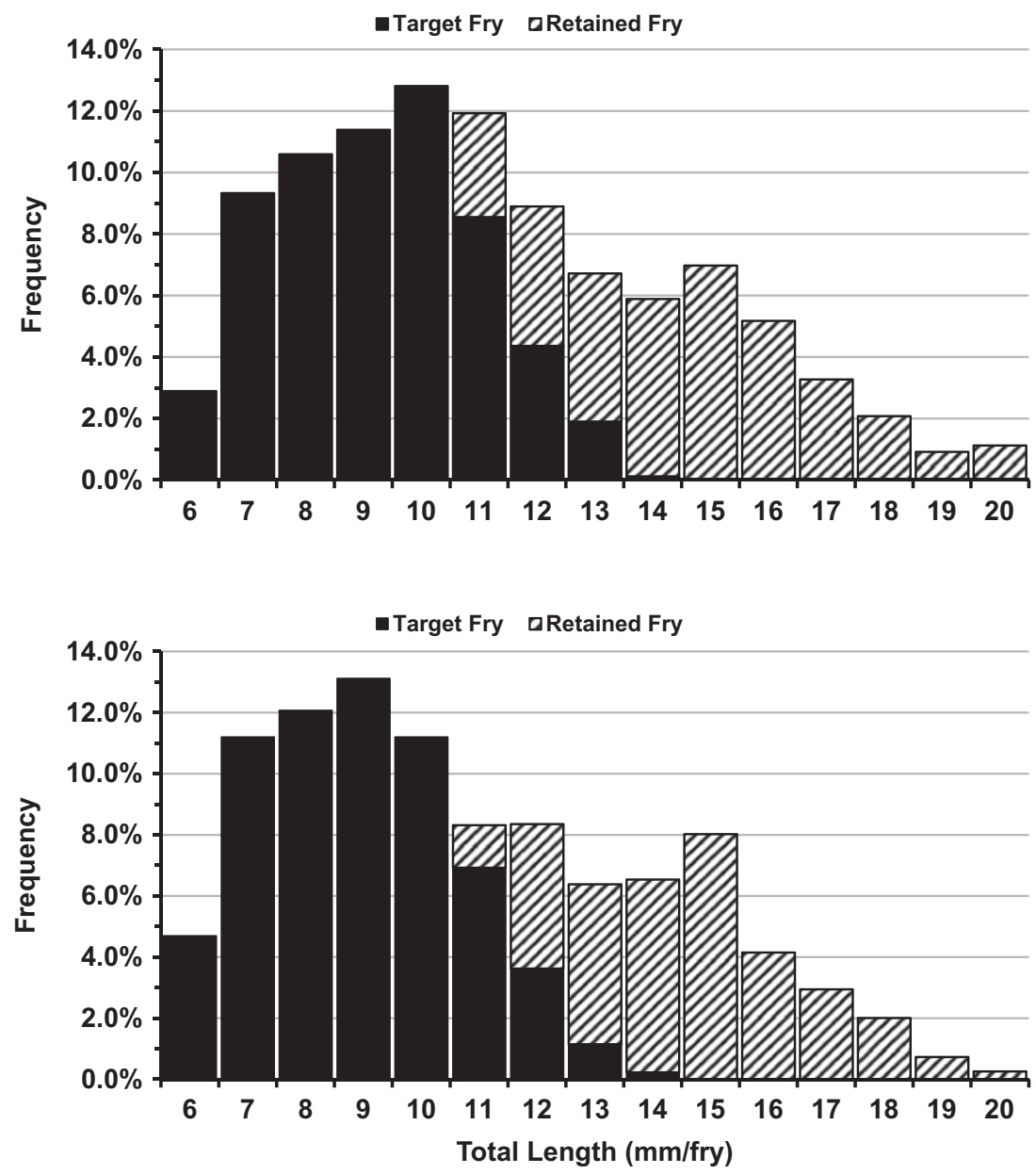

FIGURE 2 Average size distribution of Nile tilapia (top) or blue tilapia (bottom) harvested from reproduction ponds after 125-280 cumulative degree days. Fry that pass through a 3.2$\mathrm{mm}$ mesh grader range from 7 to $13 \mathrm{~mm}$ total length, are suitable for hormonal sex inversion, and are termed target fry. Degree days are calculated by subtracting $15^{\circ} \mathrm{C}$ from the average water column temperature.

Although target fry production for both species increased linearly as cumulative degree days increased from 115 to 215 degree days, optimal production appeared to occur from 190 to 215 degree days. Production of target fry for 190-215 degree days for Nile tilapia averaged $1.5 \pm 0.2$ fry/g female $(\mathrm{CV}=36.8 \%)$, which did not differ significantly $(P=0.347)$ from that for blue tilapia $(1.7 \pm 0.2 \mathrm{fry} / \mathrm{g}$ female, $\mathrm{CV}=33.8 \%)$. There was no significant difference $(P=0.154)$ between species in the production of retained fry between 190 and 215 degree days, which averaged $0.09 \pm 0.03$ fry/g female for Nile tilapia and $0.03 \pm 0.03$ fry/g female for blue tilapia. Given the common slope for production of target fry over the range of 115-215 degree 


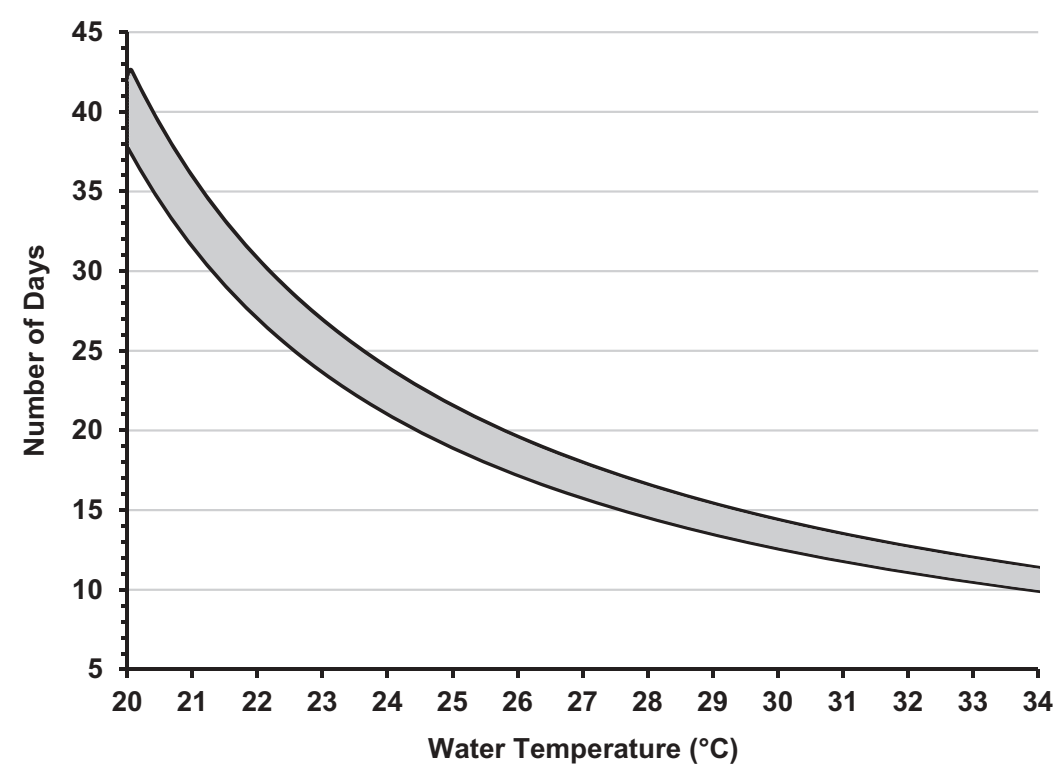

FIGURE 3 Range in number of days until reproduction pond harvest in relation to mean weekly pond water column temperature for optimal production of Nile tilapia and blue tilapia fry (7-13 mm total length) suitable for hormonal sex inversion. Optimal production in the subtropics occurs between 190 degree days (lower curve) and 215 degree days (upper curve).

days, a single equation was used to estimate the range in number of days required for optimal production of target fry for both species in relation to mean weekly water column temperature (Figure 3).

Target fry production harvested within 115-190 degree days did not differ $(P=0.861)$ between species and averaged $0.7 \pm 0.2$ fry/g female for Nile tilapia and $0.7 \pm 0.2 \mathrm{fry} / \mathrm{g}$ female for blue tilapia. Nile tilapia target fry production averaged $0.9 \pm 0.2 \mathrm{fry} / \mathrm{g}$ female when harvested at 115-190 degree days compared to $1.4 \pm 0.2$ fry $/ \mathrm{g}$ female for the period 190-215 degree days, but the difference was not statistically significant $(P=0.079)$. However, blue tilapia fry production was significantly higher $(P=0.020)$ for the 190-215 degree-days period ( $1.5 \pm 0.2 \mathrm{fry} / \mathrm{g}$ female) compared to the 115-190 degree-days period ( $0.7 \pm 0.2 \mathrm{fry} / \mathrm{g}$ female). No retained fry were observed for either species between 115 and 190 degree days.

At greater than 215 degree days, target fry production did not differ between species $(P=0.159)$ averaged $1.2 \pm 0.1$ fry $/ \mathrm{g}$ female $(\mathrm{CV}=38.0 \%)$ for Nile tilapia and $1.5 \pm 0.1$ fry $/ \mathrm{g}$ female $(\mathrm{CV}=52.1 \%)$ for blue tilapia. Target fry production did not differ significantly between the 190 and 215 and at $>215$ degree day periods within species. Retained fry at greater than 215 degree days averaged $0.5 \pm 0.2$ fry/g female $(\mathrm{CV}=82.4 \%)$ for Nile, significantly less $(P=0.029)$ than the $1.0 \pm 0.2$ fry $/ \mathrm{g}$ female $(\mathrm{CV}=88.5 \%)$ for blue tilapia. 


\section{DISCUSSION}

Pond water temperature varies seasonally in subtropical and tropical regions of the world where tilapia is cultured (Teichert-Coddington et al. 1992; Green and Teichert-Coddington 1993; Dan and Little, 2000). This seasonal variation in water temperature generally does not result in tilapia mortality but can delay tilapia reproduction. Degree days can be used to adjust for seasonal variation in water temperature when planning tilapia fingerling production strategies. When water temperatures are cooler, greater time can be allowed for optimal tilapia reproduction, and less time is required at warmer temperatures.

Production of large numbers of Nile tilapia and blue tilapia fry suitable for hormonal sex inversion based on using degree days to set harvest was demonstrated for earthen ponds in a subtropical climate. Both species had similar total and target fry productivities and onsets and peak production periods in terms of cumulative degree days. Nile tilapia production in response to degree days in the present study extends to a subtropical climate on a different continent in the relationship reported by Green and TeichertCoddington (1993) for a tropical climate. In their study, optimal production of Nile tilapia target fry occurred from 195 to 220 cumulative degree days. The present research also quantified for the first time the relationship between blue tilapia fry production and degree days and showed the relationship to be similar to that for Nile tilapia. In practical terms, tilapia fry production in ponds in a subtropical climate was limited to periods when water temperature exceeded $20^{\circ} \mathrm{C}$, whereas fry production continued year-round in the tropical climate. Fry production for the current study began with stocking broodfish in ponds in April and continued through the end of October, which is similar to the tilapia fry production season reported for subtropical climate (Hulata 1997; Dan and Little, 2000). Tilapia fry produced late in the season may be overwintered in order to take full advantage of the next growing season (Dan and Little, 2000), or production may cease in August or September because of reduced demand (Hulata 1997).

Variation in total fry production across all trials in the present experiment was high and was consistent with the variability noted by others (Berrios-Hernandez and Snow 1983; Siraj et al. 1983; Hughes and Behrends 1983; Aureli and Torrans 1988; Behrends et al. 1993). As the cumulative degree days increased, greater numbers of fry exceeded the target fry size range because of the additional time and/or higher temperatures available for growth. More variable fry productivity at higher cumulative degree days could be partially the result of predation on sac fry by larger fry (BerriosHernández and Snow 1983; Pantastico et al. 1988). However, as part of fry pond management in this study, we followed the recommendation of Popma and Green (1990) that puddles remaining on the pond bottom after each harvest be treated with chlorine to eliminate any trapped fry that could prey 
upon sac fry produced during the subsequent production cycle. Additionally, any eggs or sac fry were removed from brooding females prior to stocking reproduction ponds in the present experiment.

Female age may have contributed to the variability observed in fry production between Nile tilapia and blue tilapia. Although broodfish used for the current work were selected from age indeterminate populations, Nile tilapia females were about 60\% larger than blue tilapia females. Based on mean individual weight, Nile females likely were 2 years old, whereas blue tilapia females likely were 1 year old. Siraj et al. (1983) showed that fingerling output from Nile females, which incorporates spawning rate, fecundity, hatchability, and fry survival, was significantly greater for year class I females than for year classes II and III. Behrends et al. (1993) reported for blue tilapia (year class II) reproduction in hapas that over the spawning season clutch size remained relatively constant, but spawning rate tended to decline. The number of females in the population that spawn increases with age: for Nile tilapia, 64\% of year class I, 69\% of year class II, and 80\% of year class III females spawned (Siraj et al. 1983) and for blue tilapia, 75\% of year class I (Aureli and Torrans 1988) and 90\% of year class II (Behrends et al. 1993) females spawned.

Interspawning interval is another factor known to affect tilapia fry productivity. Interspawning interval ranged from 7 to $12 \mathrm{~d}$ for year class I and II Nile females and from 10 to $20 \mathrm{~d}$ for year class III females, and spawning rate over successive spawns remained unchanged in year class I females but declined in year class II and III females (Siraj et al. 1983). Year class I blue females had an interspawning interval of 8-14 d (Aureli and Torrans 1988), whereas year class II females had an interspawning interval of 12-15 d (Behrends et al. 1993). Based on individual weight, female brood fish used in the present trials were presumed to be no older than year class II and to have spawned only once during each trial. The shorter interspawning intervals reported for Nile and blue tilapia occur when all seed (eggs, sac fry, and fry) are collected at frequent intervals from mouth-brooding females. Although females were not checked for seed while in ponds in the present work, their interspawning interval likely was short because of the relatively short time fish were in ponds and the removal of all seed from any brooding female before pond stocking.

Optimal production of Nile tilapia and blue tilapia fry suitable for sex inversion was achieved in the subtropics by harvesting reproduction ponds between 190 and 215 cumulative degree days. Because water temperature increases from the spring through the summer and then declines, a variable number of days is required to attain this range of degree days. The relationship shown in Figure 3 serves as a guide to producers in the subtropics or at higher elevations in the tropics. For example, a reproduction pond should be harvested after 27-31 d at a mean weekly water column temperature of $22^{\circ} \mathrm{C}$, but after $13-14 \mathrm{~d}$ at a mean water temperature 
of $30^{\circ} \mathrm{C}$. Water temperature can be measured on a daily basis to time harvests precisely when water temperature cycles for a particular site have not been quantified or when unexpected weather fronts occur. Estimated degree days can be used to plan harvests once water temperature cycles are well defined.

Degree days was shown to be a good predictor for pond production in the subtropics of Nile tilapia and blue tilapia fry for hormonal sex inversion and confirmed results obtained for Nile tilapia in the tropics. Degree days also would be expected to apply to egg production from spawning hapa-based hatchery operations that collect and incubate fertilized eggs. This would be a fruitful area for research.

\section{ACKNOWLEDGMENTS}

We thank Ahmed Nassr Alla, Ahmed Khater, and Abdel R. El Gamal for their collaboration during this study, and Drs. Les Torrans, Ronald Phelps, and Marty Riche for reviewing a draft of this article.

\section{FUNDING}

This research was a component of the Pond Dynamics/Aquaculture Collaborative Research Support Program funded by the U.S. Agency for International Development. Mention of trade names or commercial products in this article is solely for the purpose of providing specific information and does not imply recommendation or endorsement by the U.S. Department of Agriculture.

\section{REFERENCES}

Aureli, T. J., and L. Torrans. 1988. Spawning frequency and fecundity of blue tilapia. Proceedings Arkansas Academy of Science 42:108.

Beardmore, J. A., G. C. Mair, and R. I. Lewis. 2001. Monosex male production in finfish as exemplified by tilapia: Applications, problems, and prospects. Aquaculture 197:283-301. doi:10.1016/S0044-8486(01)00590-7.

Behrends, L. L., J. B. Kingsley, and A. H. Price III. 1993. Hatchery production of blue tilapia, Oreochromis aureus (Steindachner), in small suspended hapa nets. Aquaculture and Fisheries Management 24:237-243.

Berrios-Hernández, J. M., and J. R. Snow. 1983. Comparison of methods for reducing fry losses to cannibalism in tilapia production. The Progressive Fish-Culturist 45:116-118. doi:10.1577/1548-8659(1983)45[116:COMFRF]2.0.CO;2.

Dan, N. C., and D. C. Little. 2000. Overwintering performance of Nile tilapia Oreochromis niloticus (L.) broodfish and seed at ambient temperatures in 
northern Vietnam. Aquaculture Research 31:485-493. doi:10.1046/j.1365-2109. 2000.00466.x.

Green, B. W., and D. R. Teichert-Coddington. 1993. Production of Oreochromis niloticus fry for hormonal sex reversal in relation to water temperature. Journal of Applied Ichthyology 9:230-236. doi:10.1111/jai.1993.9.issue-3-4

Guerrero, R. D. III. 1986. Production of Nile tilapia fry and fingerlings in earthen ponds at Pila, Laguna, Philippines. In The first Asian fisheries forum, ed. J. L. Maclean, L. B. Dizon, and L. V. Hosillos, 49-52. Manila: Asian Fisheries Society.

Hughes, D. G., and L. L. Behrends. 1983. Mass production of Tilapia nilotica seed in suspended net enclosures. In International Symposium on Tilapia in Aquaculture Proceedings, ed. L. Fishelson and Z. Yaron, 394-401. Tel Aviv: Tel Aviv University.

Hulata, G. 1997. Large-scale tilapia fry production in Israel. Israeli Journal of Aquculture-Bamidgeh 49:174-179.

Khater, A. Z., and R. O. Smitherman. 1988. Cold tolerance and growth of three strains of Oreochromis niloticus. In The Second International Symposium on Tilapia in Aquaculture, ed. R. S. V. Pullin, T. Bhukaswan, K. Tonguthai, and J. L. Maclean, 215-218. Manila: International Center for Living Aquatic Resources Management.

Pantastico, J. B., M. M. A. Dangilan, and R. V. Eguia. 1988. Cannibalism among different sizes of tilapia (Oreochromis niloticus) fry/fingerlings and the effect of natural food. In The Second International Symposium on Tilapia in Aquaculture, ed. R. S. V. Pullin, T. Bhukaswan, K. Tonguthai, and J. L. Maclean, 465-468. Manila: International Center for Living Aquatic Resources Management.

Popma, T. J., and B. W. Green. 1990. Aquaculture production manual: Sex reversal of tilapia in earthen ponds. Auburn, AL: Auburn University. http:// www.ag.auburn.edu/fish/documents/International_Pubs/R\&D\%20Series/35\%20 -\%20Sex\%20Reversal\%20of\%20Tilapia\%20in\%20Earth\%20Ponds.pdf （accessed November 17, 2014).

Pruess, K. P. 1983. Day-degree methods for pest management. Environmental Entomology 12:613-619. doi:10.1093/ee/12.3.613.

Regier, H. A., J. A. Holmes, and D. Pauly. 1990. Influence of temperature changes on aquatic ecosystems: An interpretation of empirical data. Transactions of the American Fisheries Society 119:374-389. doi:10.1577/1548-8659(1990)119<0374: IOTCOA $>2.3 . \mathrm{CO} ; 2$.

Rezk, M. A., E. A. Kamel, A. A. Ramadan, and R. A. Dunham. 2002. Comparative growth of Egyptian tilapias in response to declining water temperature. Aquaculture 207:239-247. doi:10.1016/S0044-8486(01)00748-7.

Rothbard, S., E. Solnik, S. Shabbath, R. Amado, and I. Grabie. 1983. The technology of mass production of hormonally sex-inversed all-male tilapias. In International Symposium on Tilapia in Aquaculture Proceedings, ed. L. Fishelson and Z. Yaron, 425-434. Tel Aviv: Tel Aviv University.

Siraj, S. S., R. O. Smitherman, S. Castillo-Gallusser, and R. A. Dunham. 1983. Reproductive traits for three year classes of Tilapia nilotica and maternal effects on their progeny. In International Symposium on Tilapia in Aquaculture Proceedings, ed. L. Fishelson and Z. Yaron, 210-218. Tel Aviv: Tel Aviv University. 
Starling, S. M., R. M. Bruckler, R. K. Strawn, and W. H. Neill. 1995. Notes: Predicting the lethality of fluctuating low temperatures to blue tilapia. Transactions of the American Fisheries Society 124:112-117. doi:10.1577/1548-8659(1995)124<0112: NPTLOF $>2.3 . \mathrm{CO} ; 2$.

Teichert-Coddington, D. R., B. W. Green, and R. P. Phelp. 1992. Influence of site and season on water quality and tilapia production in Panama and Honduras. Aquaculture 105:297-314. doi:10.1016/0044-8486(92)90094-2.

Verdegem, M. C., and A. S. McGinty. 1989. Evaluation of edge seining for harvesting Oreochromis niloticus fry from spawning ponds. Aquaculture 80:195-200. doi:10.1016/0044-8486(89)90285-8. 